\title{
Poem
}

\section{A Year On}

\section{Trevi-jean Le Père}

when you had been

simmering and bubbling and squirming and kicking

almost 10 months in my belly

and so much longer in my heart and mind and soul,

I thought, "this is the littlest person I've ever waited so long for."

then when after almost 4 days of

liquid-metal-drop-through-spine-out-like-waves-through-my-legs

and kneeling and breathing and swearing quietly

and that leather cutting snip

they said, "put your hand down and feel your baby"

and I touched your little big soft head.

I thought, "this is the littlest person I've ever worked this hard for."

and when they put you on my emptying belly

blue and so warm and wet and crying

big eyes saying so we finally meet and my name is Simone after all

and then my huge nipple and your tiny mouth

I thought, "this is the littlest person I've ever been scared of."

And too soon after those early days of the two of us

doze-wake-sit-up-burp-latch-doze

you stretching your little stretch

so warm and soft from sleep

one day you woke before me sat up

smiled looked out of the window

I saw you grab a sunbeam

to put in your mouth

you turned your head and I saw

sunset flicker on your lashes

and I thought, "you are the most beautiful person I've ever woken up to."

And today a year has passed since we first met

I see you toddle round the house playing boo

kicking a ball as you shout at it

call to the flowers and the dog and look for me

with your mumumum and your great big smile

and your arms outstretched and you hug my knees

and blow me a kiss and give me a thread

I think, "this is the only person I've ever loved with every fibre of my being"

and I think "this love pain is worse than my labour pain"

and I think "but you're the same little girl who came to me then"

and I think "I thank you for making me a different woman." 